\title{
Genetic Characterization and Relationships among Egyptian Lentil Cultivars as Revealed By Biochemical and Molecular Markers
}

\author{
Hala Mahfouz ${ }^{\#}$ and Walaa Abuelwafa Rayan \\ Unit of Plant Genetics, Department of Botany, Faculty of Science, Ain Shams \\ University, Cairo, Egypt.
}

\begin{abstract}
T ENTIL (Lens culinaris Medikus) is an important seed legume crop cultivated worldwide

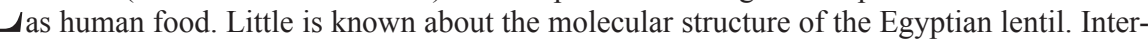
varietal variation and cultivar identification are crucial for breeding and gene bank conservation of this plant worldwide. The SDS-PAGE and SRAP-PCR techniques were used to detect some biochemical and molecular markers of six Egyptian lentil genotypes (Sinai 1, Line 9, Giza 1, Giza 4, Giza 51 and Giza 370). The genetic distance between cultivars was also estimated from banding patterns. The results of SDS-PAGE revealed a total of 21 bands with molecular weight ranging from about to 6-102 KD. The maximum number of bands (14) appeared in Giza 4, while the minimum number of bands (10) appeared in Giza 1. Electrophoresis analysis among six lentil cultivars showed $80.95 \%$ polymorphism, while DNA variations were explored using ten combinations of SRAP markers. SRAP analysis among six lentil cultivars showed $61.54 \%$ polymorphism. The highest similarity index (0.869) was found between Giza 51 and Giza 370 . The lowest similarity index (0.603) was found between Giza 1 and Giza 4. The markers used in this study created polymorphic bands among the different cultivars that can be utilized as molecular markers for their differentiation. The obtained data indicated that SRAP and SDSPAGE systems can efficiently identify and differentiate between the selected cultivars. Also these results, enhancing the available knowledge of lentil genetic resources in Egypt, may contribute to their conservation and utilization in breeding programs.
\end{abstract}

Keywords: Egyptian lentil, Genetic diversity, Phylogenetic tree, SDS-PAGE, SRAP marker.

\section{Introduction}

Lentil (Lens culinaris Medikus) is an annual diploid $(2 \times=2 n=14$ chromosomes) species belonging to the Fabaceae. It is one of the most substantial grain legumes in the world after chickpea (Cicer arietinum L.) and pea (Pisum sativum L.). Lentils contain high levels of proteins (22\%-34.6\%), including some important amino acids such as lysine, arginine and leucine (Thavarajah et al., 2011). It also has high levels of carbohydrates $(55 \%-59 \%)$ and appreciable levels of micronutrients and vitamins (USDA 2013). Most of the lentil growing countries face certain sets of abiotic and biotic stresses causing considerable reduction in crop growth, yield and production. Lentil breeders have applied conventional plant breeding methods of selection to promote improved cultivars (Kumar et al., 2015).

Traditional techniques of plant breeding have made a substantial contribution to crop improvement but they proved to be slow in targeting a complex trait like grain yield and drought or salinity tolerance. Biotechnology offers novel and powerful tools to assist and complement the breeding efforts (Frederick et al., 2006). Seed protein patterns gained by gel electrophoresis have been successfully applied to distinguish cultivars of a particular crop species (Karihaloo et al., 2002 and Sammour, 2014). It provides a powerful, relatively appropriate and rapid method of identification and classification of gene bank collection that is used to distinguish between genotypes (Pedalino et al., 1992 and Berber \& Yasar, 2011).The technique is economical, simple and rapid. This kind of information will enable breeders to develop highly sustainable crops through a well-organized breeding plan.

Few molecular genetics and genomic resources existed for lentil, partly due to its relatively large genome size (Khazaei et al., 2016). Assessment of genetic diversity of different crop species is appropriate precursor for improvement of the crop because it generates baseline data to guide selection of parental lines. Evaluation of crop genetic variation is critical to understanding the available genetic variability and potential use for varietal improvement through breeding programs (Hayward \& Breese, 1993 and Tello-Ruiz et al., 2016).

\#Corresponding author email: hala.mahfouz@yahoo.com

Walaa Abuelwafa Rayan email: walaagenetics@yahoo.com

DOI :10.21608/ejbo.2017.1049.1093

(C)2018 National Information and Documentation Center (NIDOC) 
Molecular biology has contributed to the development of DNA- based markers that can be used for genotype identification, fingerprinting, genetic mapping and diversity assessment (Sonnante \& Pignone, 2001; Zaccardelli et al., 2012 and Khazaei et al., 2016). The genetic diversity of Lens culinaris Medik. has been examined with a number of molecular marker systems, including: restriction fragment length polymorphism (Havey \& Muehlbauer, 1989), random amplified polymorphic DNA assay (Alvarez et al., 1997), amplified fragment length polymorphism (Toklu et al., 2009), Inter simple sequence repeat (El-Nahas et al., 2011), and simple sequence repeat markers (Hamwieh et al., 2009; Kaur et al., 2011 and Kushwaha et al., 2015). Sequence-related amplified polymorphism (SRAP) is an easy and functional molecular marker technique used for genetic diversity and phylogenetic studies in different legume crops $(\mathrm{Li}$ et al., 2009; Baloch et al., 2010; Castonguay et al., 2010 and Alghamdi et al., 2012). SRAP markers are more potent for revealing genetic diversity among closely related cultivars than SSR, ISSR, or RAPD markers (Budak et al., 2004) and can be utilized for linkage map construction (Yeboah et al., 2007), genomic fingerprinting (Li \& Quiros, 2001), hybrid identification (Mishra et al., 2011) and sex determination (Zhou et al., 2011). The SRAP primer system can be used without previous knowledge of DNA sequence.

Knowledge of molecular relationships between plant genotypes is useful in planning effective breeding strategies. Therefore the main objectives of this work are: (1) Determination of the molecular genetic fingerprints for the six lentil cultivars grown under the Egyptian environment using biochemical and molecular markers, (2) Determine the inter-varietal genetic polymorphism among those cultivars, and (3) Establish hypothetical molecular phylogenetic relationship between them using SRAP marker technique in order to assign suitable molecular markers for their future selection and potential breeding. To our knowledge, this is the first implementation of SRAP markers for the assessment of genetic diversity among Egyptian cultivars of Lens culinaris Medik.

\section{Materials and Methods}

Plant materials

Six Egyptian cultivars of (Lens culinaris Medikus) have been obtained from Agricultural Research Center (ARC), Giza, Egypt. The code of these six cultivars is shown in Table 1.

\section{$S D S-P A G E$}

A study of the total soluble protein in lentil seeds was made for the six genotypes by the SDSpolyacrylamide gel electrophoresis technique according to the method of Laemmli (1970). Gels were stained according to the silver staining method of Blum et al. (1987). The gel was photographed and analyzed using BIO-RAD video documentation system, Model Gel Doc, 2000.

\section{DNA extraction}

Total DNA was extracted from $100 \mathrm{mg}$ young and healthy leaf tissue of 2 week old seedlings according to the modified CTAB procedure by Doyle \& Doyle (1990). All the DNA samples were subjected to RNase treatment and further purified. The quality and quantity of different DNA samples was estimated using UV absorption spectrophotometer at $260 \mathrm{~nm}$ (Quawell Q5000 UVVis spectrophotometer, V2.1.4, USA) and diluted to $10 \mathrm{ng} / \mu \mathrm{l}$ for further use in PCR amplifications. DNA samples were stored at $-20^{\circ} \mathrm{C}$ until use for PCR analyses.

DNA bands were photographed under UV light. The size of each amplification product was automatically estimated using UV soft image analyzer system.

The SRAP analysis was performed as described by Li \& Quiros (2001). SRAP primer was screened using 10 different combinations of four forward and four reverse primers. The sequence of SRAP primers used in this work is shown in Table 2. All reagents and buffers were supplied for primers by Thermo Scientific Inc, (Germany). PCR reaction mixture was formed of $20 \mu \mathrm{l}$ reaction volume containing $10 \times$ PCR buffer (containing $25 \mathrm{mM}$ $\mathrm{MgCl}_{2}$ ), $200 \mu \mathrm{M}$ of dNTPs, $0.6 \mu \mathrm{M}$ of primers (forward and reverse), 1U Taq DNA Polymerase and $25 \mathrm{ng}$ DNA. PCR conditions included initial denaturation at $94^{\circ} \mathrm{C}$ for 4 min for 1 cycle and 10 cycles of denaturation at $94^{\circ} \mathrm{C}$ for $1 \mathrm{~min}$, primer annealing at $35^{\circ} \mathrm{C}$ for $1 \mathrm{~min}$, and primer extension at $72^{\circ} \mathrm{C}$ for $1 \mathrm{~min}$, followed by 35 cycles of denaturation at $94^{\circ} \mathrm{C}$ for $1 \mathrm{~min}$, primer annealing at $50^{\circ} \mathrm{C}$ for $1 \mathrm{~min}$, and primer extension at $72^{\circ} \mathrm{C}$ for $1 \mathrm{~min}$. The amplification was completed with a 5 min final extension at $72^{\circ} \mathrm{C}$ for 1 cycle. Amplified products were stored at $-20^{\circ} \mathrm{C}$ till further use. DNA ladder was used as molecular standard in order to confirm the appropriate SRAP markers. The amplification products were separated by electrophoresis on $1.8 \%$ agarose gel with $1 \times$ TBE buffer and stained with ethidium bromide. Electrophoresis was carried out at $60 \mathrm{~V}$ and $40 \mathrm{~mA}$ and PCR amplified products were visualized under Bio-Rad Gel Documentation system. 
TABLE 1. List of SRAP primer combinations used in the study.

Primers No. SRAP combinations primers
Sequence of primers

$\left(5^{\prime}-3^{\prime}\right)$
1
GACTGCGTACGAATTAAT

PC1(Em1+Me1 )

TGAGTCCAAACCGGATA

GACTGCGTACGAATTTGC

TGAGTCCAAACCGGATA

GACTGCGTACGAATTGAC

TGAGTCCAAACCGGATA

GACTGCGTACGAATTTGA

PC4(Em4+Me1 )

TGAGTCCAAACCGGATA

GACTGCGTACGAATTAAT

TGAGTCCAAACCGGAGC

GACTGCGTACGAATTTGC

TGAGTCCAAACCGGAGC

GACTGCGTACGAATTGAC

TGAGTCCAAACCGGAGC

GACTGCGTACGAATTTGA

TGAGTCCAAACCGGAGC

GACTGCGTACGAATTAAT

TGAGTCCAAACCGGAAT

GACTGCGTACGAATTTGC

TGAGTCCAAACCGGACC 
TABLE 2. SDS-PAGE analysis of protein patterns of six Egyptian lentil cultivars. Lanes 1, 2, 4, 5 and 6 represent cultivars Sinai 1, Line 9, Giza 1, Giza 4, Giza 51 and Giza 370, respectively.

\begin{tabular}{|c|c|c|c|c|c|c|c|c|}
\hline \multirow{2}{*}{ Band no. } & \multirow{2}{*}{$\begin{array}{c}\text { M } \\
(\mathbf{k D} .)\end{array}$} & \multirow{2}{*}{$\begin{array}{l}\text { Lane } 1 \\
\text { Sinai } 1\end{array}$} & \multirow{2}{*}{$\begin{array}{c}\text { Lane } 2 \\
\text { Line } 9\end{array}$} & \multirow{2}{*}{$\frac{\text { Lane } 3}{\text { Giza } 1}$} & \multirow{2}{*}{$\frac{\text { Lane } 4}{\text { Giza } 4}$} & \multirow{2}{*}{$\frac{\text { Lane } 5}{\text { Giza } 51}$} & \multirow{2}{*}{$\frac{\text { Lane } 6}{\text { Giza } 370}$} & \multirow[b]{2}{*}{ Polymorphism } \\
\hline & & & & & & & & \\
\hline 1 & 102 & 0 & 0 & 0 & 1 & 0 & 1 & Polymorphic \\
\hline 2 & 98 & 1 & 1 & 0 & 1 & 0 & 1 & Polymorphic \\
\hline 3 & 95 & 1 & 1 & 1 & 1 & 1 & 1 & Monomorphic \\
\hline 4 & 85 & 0 & 0 & 0 & 0 & 1 & 1 & Polymorphic \\
\hline 5 & 78 & 0 & 0 & 0 & 1 & 0 & 0 & $\begin{array}{c}\text { Polymorphic } \\
\text { (+ve unique band) }\end{array}$ \\
\hline 6 & 75 & 1 & 1 & 0 & 1 & 1 & 1 & $\begin{array}{l}\text { Polymorphic } \\
\text { (-ve unique band) }\end{array}$ \\
\hline 7 & 68 & 0 & 0 & 1 & 0 & 0 & 0 & $\begin{array}{c}\text { Polymorphic } \\
\text { (+ve unique band) }\end{array}$ \\
\hline 8 & 66 & 1 & 1 & 0 & 1 & 0 & 0 & Polymorphic \\
\hline 9 & 60 & 1 & 1 & 1 & 0 & 1 & 1 & $\begin{array}{c}\text { Polymorphic } \\
\text { (-ve unique band) }\end{array}$ \\
\hline 10 & 58 & 0 & 0 & 0 & 1 & 0 & 0 & $\begin{array}{l}\text { Polymorphic } \\
\text { (+ve unique band) }\end{array}$ \\
\hline 11 & 52 & 1 & 1 & 1 & 0 & 0 & 0 & Polymorphic \\
\hline 12 & 48 & 0 & 0 & 0 & 1 & 1 & 1 & Polymorphic \\
\hline 13 & 40 & 1 & 1 & 1 & 0 & 0 & 0 & Polymorphic \\
\hline 14 & 38 & 0 & 0 & 0 & 1 & 1 & 1 & Polymorphic \\
\hline 15 & 36 & 1 & 1 & 1 & 0 & 0 & 0 & Polymorphic \\
\hline 16 & 30 & 1 & 1 & 0 & 0 & 0 & 0 & Polymorphic \\
\hline 17 & 25 & 1 & 1 & 1 & 1 & 1 & 1 & Monomorphic \\
\hline 18 & 20 & 0 & 1 & 1 & 1 & 1 & 1 & $\begin{array}{l}\text { Polymorphic } \\
\text { (-ve unique band) }\end{array}$ \\
\hline 19 & 16 & 1 & 1 & 1 & 1 & 1 & 1 & Monomorphic \\
\hline 20 & 12 & 1 & 1 & 1 & 1 & 1 & 1 & Monomorphic \\
\hline 21 & 6 & 0 & 0 & 0 & 1 & 1 & 1 & Polymorphic \\
\hline Total $=21$ & & 12 & 13 & 10 & 14 & 11 & 13 & $\begin{array}{c}\% \text { of polymorphism } \\
\quad=80.95 \%\end{array}$ \\
\hline
\end{tabular}




\section{Band scoring and data analysis}

The SDS-PAGE and SRAP-PCR bands were visually scored as present (1) or absent (0). Only the clearest and strongest bands were recorded and used for the analysis. Data were analyzed using Sørensen's original formula (Sørensen, 1948) intended for binary data.

\section{Results and Discussion}

Seed storage proteins analysis

The SDS-PAGE for water-soluble protein was used to investigate the biochemical differences between the tested genotypes. The bands pattern (Table 2 and Fig. 1) indicates the differences among the tested genotypes in number, intensity and position of the bands. The results of SDSPAGE revealed a total of 21 bands with molecular weight ranging from about 6 to $102 \mathrm{KD}$. The maximum number of bands (14) appeared in cultivar Giza 4, while the minimum number of bands (10) appeared Giza 1. Three positive unique bands were detected in the cultivars Giza 4 (78 \&
$58 \mathrm{kD})$ and Giza $1(68 \mathrm{kD})$. Binary data obtained for absence (0) and presence (1) from protein gel electrophoresis among 6 lentil cultivars showed $80.95 \%$ polymorphism which denote the high level of protein polymorphism. Yüzbaşioğ et al. (2008) recorded 24 bands in some lentil cultivars in which only five bands were polymorphic with molecular masses ranging from 35 to $116 \mathrm{kD}$. Madina et al. (2013) stated that seed protein bands of six lentil varieties were detected at approximately molecular masses ranging between 6.5 and $66 \mathrm{kD}$ and was divided into six regions with intervals of molecular markers. Region I was for albumin protein where bands of more than 66 $\mathrm{kD}$. Region II was for ovalbumin protein, ranged from $45 \mathrm{kD}$ to $66 \mathrm{kD}$. Region III was for carbonic anhydrase protein, ranged from $29 \mathrm{kD}$ to $45 \mathrm{kD}$. Region IV was trypsin inhibitor, ranging from $20.1 \mathrm{kD}$ to $29 \mathrm{kD}$. Region V was for lysozyme and ranged from 14.4 to $20.1 \mathrm{kD}$. Region VI was for aprotinin, ranging from $6.5 \mathrm{kD}$ to $14.4 \mathrm{kD}$.

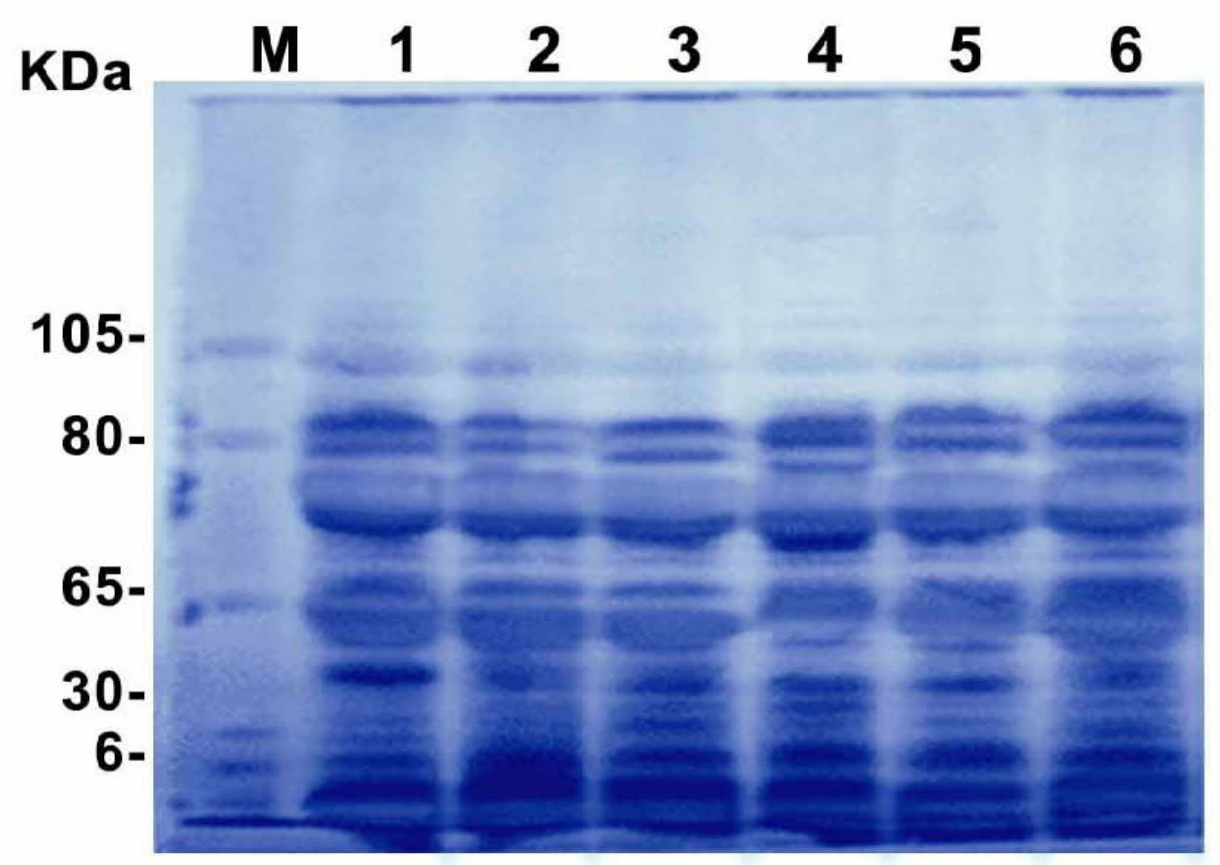

Fig. 1. SDS-PAGE analysis of protein patterns of six Egyptian lentil cultivars. $M=$ marker. Lanes 1, 2, 4, 5 and 6 represent cultivars Sinai 1, Line 9, Giza 1, Giza 4, Giza 51 and Giza 370, respectively.

\section{SRAP data analysis}

Data obtained showed that the ten combinations of SRAP primer pairs generated 39 bands in total out of which 24 bands were polymorphic among the six lentil cultivars used in this study (Tables 3 , 4 and Fig. 2). On average, each primer gave around 2-9 bands/primer with $\sim 850-75$ bp size range.
All primers used in this analysis were variably polymorphic with $77.78-33.33 \%$ range. The combination SRAP-PC1 (Em1+Me1) exhibited the highest polymorphic percentage $(77.78 \%)$, while both combinations SRAP-PC5 (Em1+Me2) and SRAP- PC6 (Em4+Me2) recorded the lowest polymorphism percentage (33.33\%). 
TABLE 3. SRAP analysis of six Egyptian lentil cultivars. Lanes 1, 2, 3, 4, 5 and 6 represent cultivars Sinai 1, Line 9, Giza 1, Giza4, Giza 51 and Giza370, respectively.

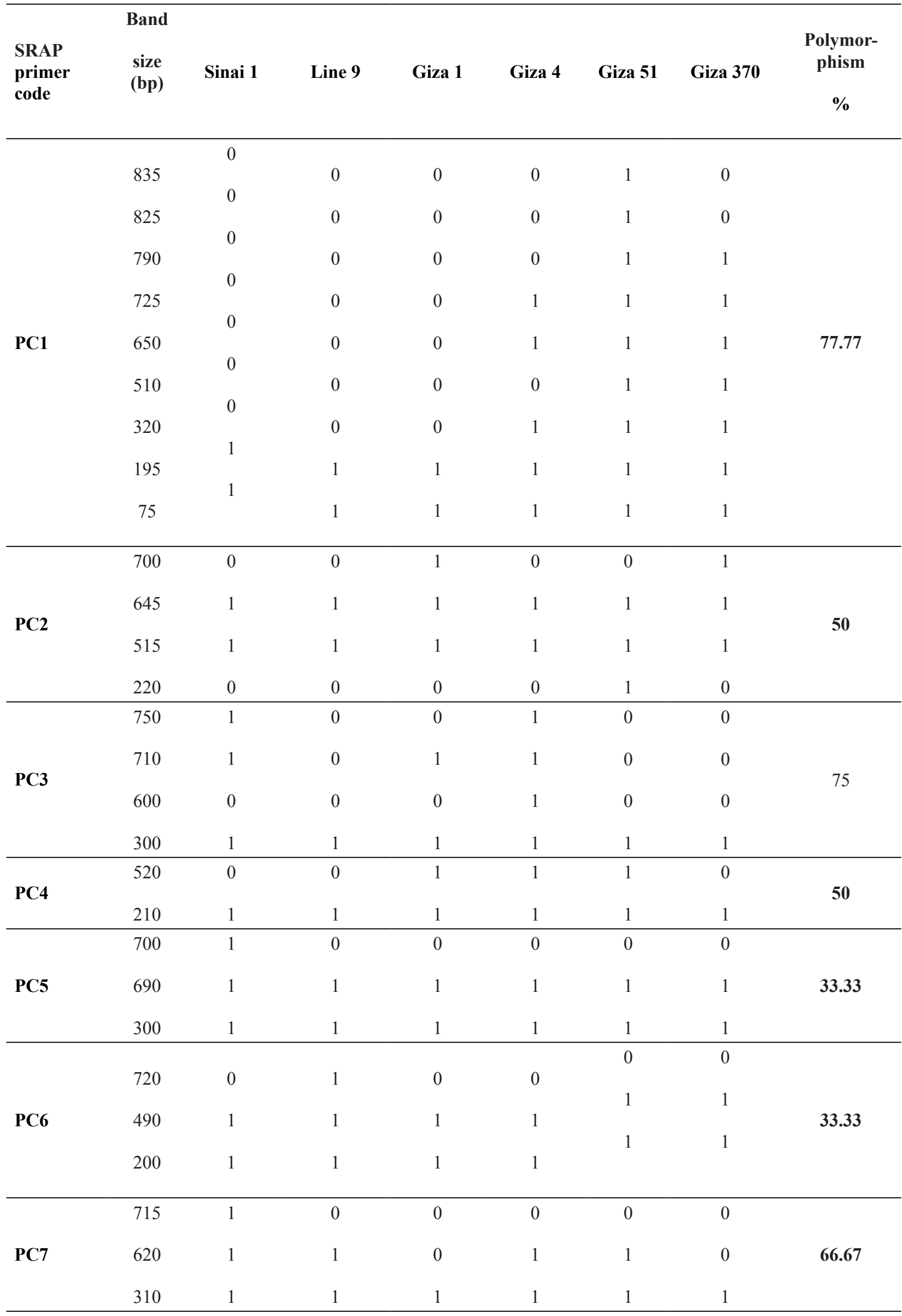

Egypt. J. Bot. 58, No.1 (2018) 
TABLE 3. Cont.

\begin{tabular}{|c|c|c|c|c|c|c|c|c|}
\hline $\begin{array}{l}\text { SRAP } \\
\text { primer } \\
\text { code }\end{array}$ & $\begin{array}{l}\text { Band } \\
\text { size } \\
\text { (bp) }\end{array}$ & Sinai 1 & Line 9 & Giza 1 & Giza 4 & Giza 51 & Giza 370 & $\begin{array}{c}\text { Polymor- } \\
\text { phism } \\
\%\end{array}$ \\
\hline \multirow{6}{*}{ PC8 } & 850 & 1 & 0 & 0 & 0 & 0 & 0 & \multirow{6}{*}{66.67} \\
\hline & 800 & 0 & 1 & 0 & 0 & 0 & 0 & \\
\hline & 680 & 0 & 1 & 0 & 0 & 0 & 1 & \\
\hline & 510 & 1 & 1 & 1 & 1 & 1 & 1 & \\
\hline & 505 & 1 & 1 & 1 & 1 & 1 & 1 & \\
\hline & 400 & 0 & $\mathbf{0}$ & 0 & 0 & 1 & 1 & \\
\hline \multirow{3}{*}{ PC9 } & 520 & 1 & 0 & 0 & 1 & 1 & 0 & \multirow{3}{*}{66.67} \\
\hline & & 1 & 0 & 0 & 1 & 1 & 0 & \\
\hline & $\begin{array}{l}480 \\
200\end{array}$ & 1 & 1 & 1 & 1 & 1 & 1 & \\
\hline \multirow{2}{*}{ PC10 } & 750 & 0 & 1 & 0 & 0 & 0 & 0 & \multirow{2}{*}{50.00} \\
\hline & 400 & 1 & 1 & 1 & 1 & 1 & 1 & \\
\hline Total & 39 & 23 & 20 & 18 & 25 & 28 & 23 & $61.54 \%$ \\
\hline
\end{tabular}

TABLE 4. Total number of bands, monomorphic and polymorphic bands and percentage of polymorphism as revealed by SRAP markers among six lentil cultivars.

\begin{tabular}{|c|c|c|c|c|c|c|c|}
\hline \multirow{2}{*}{$\begin{array}{l}\text { SRAP } \\
\text { primer } \\
\text { code }\end{array}$} & \multirow{2}{*}{$\begin{array}{l}\text { Total } \\
\text { No. of } \\
\text { bands }\end{array}$} & \multirow{2}{*}{$\begin{array}{l}\text { Average } \\
\text { band } \\
\text { size (bp) }\end{array}$} & \multirow[t]{2}{*}{$\begin{array}{l}\text { Monomo- } \\
\text { rphic bands }\end{array}$} & Pol & orphic & \multirow{2}{*}{$\begin{array}{c}\text { Polymor- } \\
\text { phism } \\
\%\end{array}$} & \multirow{2}{*}{$\begin{array}{l}\text { No. of bands } \\
\text { In each } \\
\text { cultivar }\end{array}$} \\
\hline & & & & Unique & Non unique & & \\
\hline PC1 & 9 & $835-75$ & 2 & 2 & 5 & 77.78 & 23 (Sinai 1) \\
\hline $\mathrm{PC} 2$ & 4 & $700-220$ & 2 & 1 & 1 & 50.00 & 20 (Line 9) \\
\hline PC3 & 4 & $750-300$ & 1 & 1 & 2 & 75.00 & \multirow{2}{*}{18 (Giza 1) } \\
\hline PC4 & 2 & $520-210$ & 1 & 0 & 1 & 50.00 & \\
\hline PC5 & 3 & $700-300$ & 2 & 1 & 0 & 33.33 & \multirow{2}{*}{25 (Giza4) } \\
\hline PC6 & 3 & $720-200$ & 2 & 1 & 0 & 33.33 & \\
\hline PC7 & 3 & $715-310$ & 1 & 1 & 1 & 66.67 & \multirow{2}{*}{28 (Giza 51) } \\
\hline PC8 & 6 & $850-400$ & 2 & 1 & 3 & 66.67 & \\
\hline PC9 & 3 & $520-200$ & 1 & 0 & 2 & 66.67 & \multirow{2}{*}{23 Giza370) } \\
\hline $\mathrm{PC} 10$ & 2 & $750-400$ & 1 & 1 & 0 & 50.00 & \\
\hline Total & 39 & & 15 & 9 & 15 & $61.54 \%$ & \\
\hline
\end{tabular}



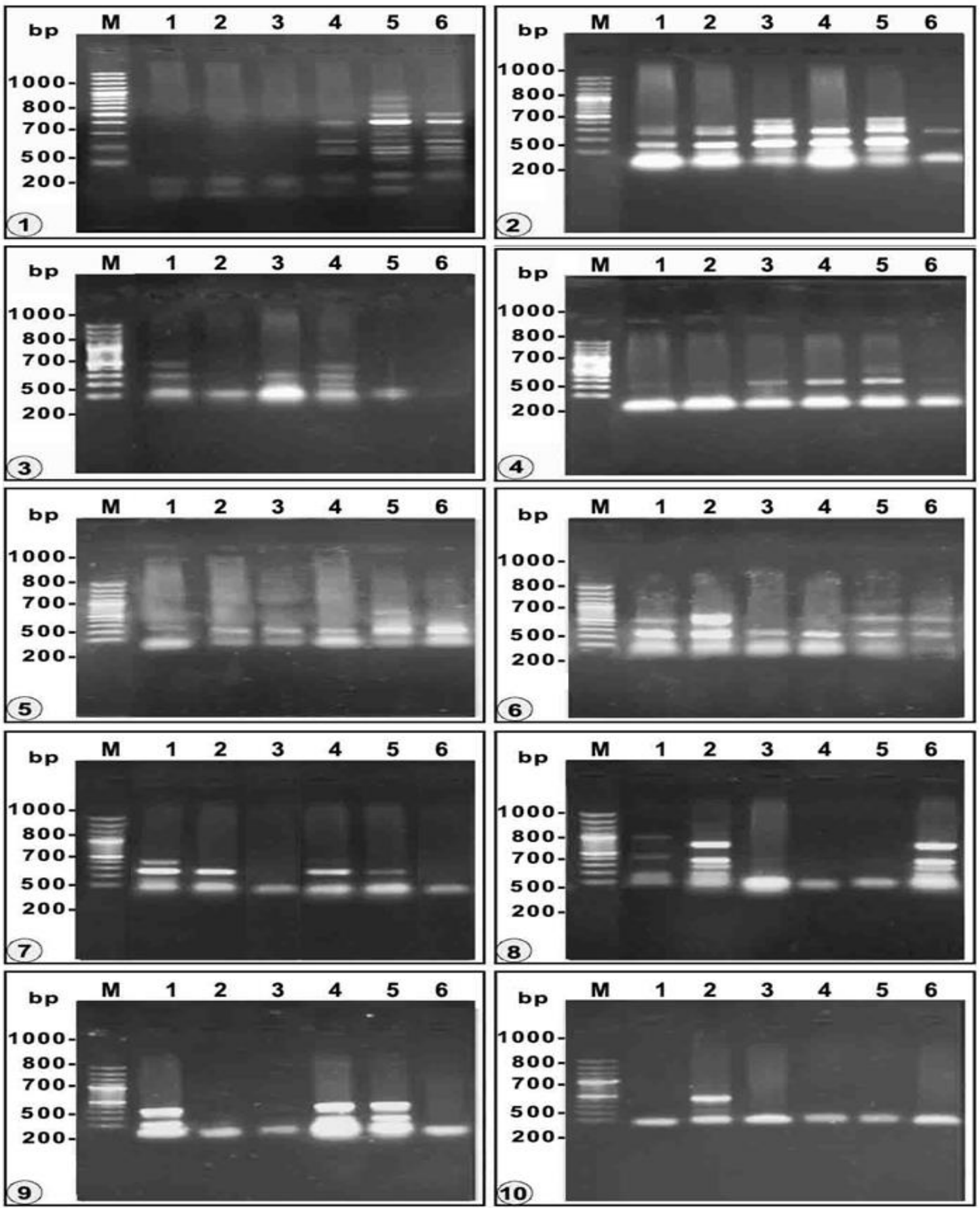

Fig. 2. The separation pattern of the SRAP products on $1.8 \%$ agarose gel using the primers: PC 1, PC 2, PC 3, PC 4, PC 5, PC 6, PC1 7, PC1 8, PC9 and PC 10. M: 1 kb ladder DNA marker. Lanes 1, 2, 4, 5 and 6 represent cultivars: Giza 51, Line 9, Giza 1, Giza 4, Sinai 1 and Giza 370, respectively. 
SRAP-PC1 (Em1+Me1) generated two unique bands with Giza 51. SRAP-PC2 (Em2+Me1) generated one unique band with Giza 51. SRAPPC3 (Em3+Me1) generated one unique band with Giza 4. SRAP-PC5 (Em1+Me2) generated one unique band with Sinai 1. SRAP-PC6 (Em2+Me2) generated one unique band with Line 9. SRAPPC7 (Em3+Me2) generated one unique band with Sinai 1. SRAP-PC8 (Em4+Me2) generated two unique band with Sinai 1 and Line 9. SRAPPC10 (Em2+Me4) generated one unique band with Line 9.

The average of overall polymorphism percentage generated with all primers was $61.54 \%$. SRAP exhibited highe polymorphism $(61.54 \%)$ compared to $(80.95 \%)$ in SDS-PAGE analysis. The overall result gives insight about the potential of Egyptian lentil cultivars to modify their DNA particularly in the presence of a high selection pressure. The current lentil breeding programs are limited in their capability to perform marker assessed selection (MAS) due to a lack of genomic resources. In comparison to prime legume crops such as soybean, common bean, pigeon pea, and chickpea, the speed of development of genomic resources is late in lentil (Kumar et al., 2015). Large genome size, narrow genetic base, low density linkage map, and the difficulty in identifying beneficial alleles are the central limiting agents in genomics-enabled improvement in lentil. In the past, the restricted availability of genomic resources in lentil could not permit breeders to employ these tools in main stream breeding program (Kumar et al., 2015). Molecular tools have been used by lentil breeders and geneticists to realize the genetic basis of a few traits linked to biotic and abiotic stresses (Kumar et al., 2014). Genomics-assisted breeding is relatively potent and fast to develop high yielding varieties more suited to adverse environmental conditions. New tools such as molecular markers are predictable to create new awareness and improve our understanding of the genetics of complex traits.

Genetic similarity analysis based on SDS-PAGE and SRAP

The results generated from seed protein and SRAP profiles were pooled for drawing the relationships among the six lentil cultivars under study. The similarity indices among these cultivars were estimated for each pair-wise group (Tables 5, 6 and 7). The similarity relationships based on protein analysis ranged from 0.960 to 0.416 (Table 5). The highest similarity index (0.960) was found between Sinai 1 and Line 9, while the lowest similarity index (0.416) was found between Giza 1 and Giza 4.

TABLE 5. Genetic similarity matrices among six lentil cultivars as computed according to Sorensen coefficient from SDS-PAGE analysis.

\begin{tabular}{|c|c|c|c|c|c|c|}
\hline & Sinai 1 & Line 9 & Giza 1 & Giza 4 & Giza 51 & Giza 370 \\
\hline Sinai 1 & 0.00 & & & & & \\
\hline Line 9 & 0.960 & 0.00 & & & & \\
\hline Giza 1 & 0.727 & 0.782 & 0.00 & & & \\
\hline Giza 4 & 0.538 & 0.592 & 0.416 & 0.00 & & \\
\hline Giza 51 & 0.521 & 0.583 & 0.571 & 0.720 & 0.00 & \\
\hline Giza 370 & 0.560 & 0.615 & 0.521 & 0.814 & 0.916 & 0.00 \\
\hline
\end{tabular}


TABLE 6. Genetic similarity matrices among six lentil cultivars as computed according to Sorensen coefficient from SRAP analysis.

\begin{tabular}{|c|c|c|c|c|c|c|}
\hline & Sinai 1 & Line 9 & Giza 1 & Giza 4 & Giza 51 & Giza 370 \\
\hline Sinai 1 & 0.00 & & & & & \\
\hline Line 9 & 0.744 & 0.00 & & & & \\
\hline Giza 1 & 0.780 & 0.789 & 0.00 & & & \\
\hline Giza 4 & 0.833 & 0.711 & 0.790 & 0.00 & & \\
\hline Giza 51 & 0.705 & 0.666 & 0.695 & 0.830 & 0.00 & \\
\hline Giza 370 & 0.652 & 0.744 & 0.780 & 0.750 & 0.823 & 0.00 \\
\hline
\end{tabular}

TABLE 7. Genetic similarity matrices among six lentil cultivars as computed according to Sorensen coefficient from SDS-PAGE and SRAP analysis.

\begin{tabular}{|c|c|c|c|c|c|c|}
\hline & Sinai 1 & Line 9 & Giza 1 & Giza 4 & Giza 51 & Giza 370 \\
\hline Sinai 1 & 0.00 & & & & & \\
\hline Line 9 & 0.852 & 0.00 & & & & \\
\hline Giza 1 & 0.753 & 0.785 & 0.00 & & & \\
\hline Giza 4 & 0.685 & 0.651 & 0.603 & 0.00 & & \\
\hline Giza 51 & 0.613 & 0.624 & 0.633 & 0.775 & 0.00 & \\
\hline Giza370 & 0.606 & 0.679 & 0.650 & 0.782 & 0.869 & 0.00 \\
\hline
\end{tabular}

Similarity indices among the 6 lentil cultivars based on SRAP analysis is given in Table 6. The highest similarity index 0.833 was recorded between the two cultivars Giza 4 and Sinai 1. The lowest similarity index (0.652) was recorded between the two cultivars Giza 370 and Sinai 1 indicating that these cultivars are genetically distant (Table 6). The similarity coefficient which resulted from the combined data of SDS- PAGE and SRAP techniques ranged from 0.869 to 0.603 (Table 7). The lowest similarity index (0.603) was observed between two cultivars Giza 1 and Giza 4 while, highest similarity index (0.869) was recorded between the two cultivars Giza 370 and Giza 51. The higher the similarity coefficient between two genotypes, the more the similarity between them based on protein bands (Aghili \& Yousef, 2012). Sharma et al. (1996) obtained similar results using AFLP and RAPD marker to appreciate and examine the genetic diversity and phylogeny of 54 lentil accessions. On the other hand, Kushwaha et al. (2015) and Dharmendra et al. (2016) using SSR markers showed a broad range of genetic variability between ninety-six lentil genotypes due to their different origin and different genetic constitution. Cluster analysis indicated the dimension of genetic diversity that is a practical use in plant breeding (Sultana et al., 2006).

\section{Conclusions}

Considering all the gained data, it is evident that molecular marker SRAP is a good tool in assessing genetic variation among the six cultivars of lentil. These markers provide interesting tool for breeding new varieties in Egyptian lentil. In conclusion, although all of the techniques facilitate to resolve issues related to genetic diversity in lentil, both seed proteins and SRAP gave high levels of genetic diversity. Also, the results of this investigation provided some SRAP molecular markers associated with lentil genotypes productivity.

Acknowledgment: The authors are grateful to Prof. Hoda Barakat Professor of Genetics, Botany Department, Faculty of Science, Ain 
Shams University, for her kind help, generous contributions and continuous guidance.

\section{$\underline{\text { Referances }}$}

Aghili, A.I.A. and Yousef, A. (2012) A study on genetic diversity in lentil genotypes using seeds morphologic and protein traits. Life Sci. J. 9, 4099-4106.

Alghamdi, S.S., Al-Faifi, S.A., Migdadi, H.M., Khan, M.A., El-Harty, E.H. and Ammar, M.H. (2012) Molecular diversity assessment using sequence related amplified polymorphism (SRAP) markers in Vicia faba L. Int. J. Mol. Sci. 13, 16457-16471.

Alvarez, M., Garcia, P. and Perez de la Vega, M. (1997) RAPD polymorphism in Spanish lentil landraces and cultivars. J. Genet. Breed. 51, 91-96.

Baloch, F.S., Kurt, C., Arıglu, H. and Özkan, H. (2010) Assaying of diversity among soybean (Glycin max L. Merr.) and peanut (Arachis hypogaea L.) genotypes at DNA level. Turk. J. Agric. For. 34, 285-301.

Berber, I. and Yasar, F. (2011) Characterization of bean (Phaseolus vulgaris L.) cultivars grown in Turkey by SDS-PAGE of seed proteins. Pak. J. Bot. 43 (2), 1085-1090.

Blum, H., Beier, H. and Gross, H.J. (1987) Improved silver staining of plant proteins, RNA and DNA in polyacrylamide gels. Electrophoresis, 8, 93-99.

Budak, H.R.C., Shearman, I., Parmaksiz, R.E., Gaussoin, T.P. and Riosdan, D. (2004) Molecular characterization of Buffalo grass germplasm using sequence-related amplified polymorphism markers. Theor. Appl. Genet. 108, 328-334.

Castonguay, Y., Cloutier, J., Bertrand, A., Michaud, R. and Laberge, S. (2010) SRAP polymorphisms associated with superior freezing tolerance in alfalfa (Medicago sativa spp. sativa). Theor. Appl. Genet. 120,1611-1619.

Dharmendra, S., Chandan, K.S., Ram, S.S.T., Tjyoti, T., Ranjeet, S., Sadhana, M., Ashish, K.C., Madan, P., Rajendra, S. and Sarawan, K.D. (2016) Molecular assortment of Lens species with different adaptations to drought conditions using SSR markers.

Doyle, J.J. and Doyle, J.L. (1990) Isolation of plant DNA from fresh tissue. Focus, 12, 13-15.

El-Nahas, A., El-Shazly, H.S. and Omran, A. (2011) Molecular and biochemical markers in some lentil (Lens culinaris Medik.) genotypes. Ann. Agric. Sci. 56,105-112.

Frederick, M., Cho, S., Sarker, A., McPhee, K., Coyne, C., Rajesh, P. and Ford, P. (2006) Application of biotechnology in breeding lentil for resistance to biotic and abiotic stress. Euphytica, 147, 149-165.

Hamwieh, A., Udupa, S.M., Sarker, A., Jung, C. and Baum, M. (2009) Development of new microsatellite markers and their application in the analysis of genetic diversity in lentils. Breed. Sci. 59, 77-86.

Havey, M.J. and Muehlbauer, F.J. (1989) Variability for restriction fragment lengths and phylogenies in lentil. Theor. Appl. Genet. 77, 839-843.

Hayward, M.D. and Breese, E.L. (1993) Population structure and variability. In: "Plant Breeding: Principles and Prospects", Hayward, M.D., Bosemark, N.O. (Ed.), pp. 7-29. Chapman and Hall: London, UK.

Karihaloo, J.M., Kaur, M. and Singh, S. (2002) Seed protein diversity in Solanum melongena L. and its wild and weedy relatives. Genet. Res. Crop Evol. 49, 533-539.

Kaur, S., Cogan, N., Pembleton, L., Shinozuka, M., Savin, K., Materne, M. and Forster, J. (2011) Transcriptome sequencing of lentil based on second-generation technology permits large-scale unigene assembly and SSR marker discovery. BMC Genomics, doi: 10.1186/1471-2164-12-265.

Khazaei, H., Caron, C.T., Fedoruk, M., Diapari, M., Vandenberg, Al., Coyne, C.J., McGee, R. and Bett, K.E. (2016) Genetic diversity of cultivated Lentil (Lens culinaris Medik.) and its relation to the world's agro-ecological zones. Front. Plant Sci. 7, 1093.

Kumar, S., Hamwieh, A., Manickavelu, A., Kumar, J., Sharma, T.R. and Baum, M. (2014) "Advances in Lentil Genomics". In: "Legumes in Omics Era," S. Gupta, N. Nadarajan, and D.S. Gupta (Ed.), pp. 111130. NewYork: Springer Science + Business Media.

Kumar, S., Rajendran, K., Kumar, J., Hamwieh, A., and Baum, M. (2015) Current knowledge in lentil genomics and its application for crop improvement. Front Plant Sci. 6,78.

Kushwaha, U.K.S., Ghimire, S.K., Yadav, N.K., Ojha, B.R. and Niroula, R.K. (2015) Genetic characterization of lentil (Lens culinaris L.) germplasm by using SSR markers. Agric. Biol. Sci. J. 1(2), 16-26.

Laemmli, U.K. (1970) Cleavage of structural proteins during assembly of head bacteriophage T4. Nature, 227, 680-685.

Li, G.Y. and Quiros, C.F. (2001) Sequence-related amplified polymorphism (SRAP), a new marker system based on a simple PCR reaction, its application to mapping and gene tagging in Brassica. Theor. Appl. Genet. 103, 455-461.

Li, Y., Fan, X., Shi, T. and Zhang, Z. (2009) SRAP marker reveals genetic diversity in tartary buck wheat in China. Front Agric. 3(4), 383-387.

Madina, M.H., Haque, M.E., Dutta, A.K., Islam, M.A., Deb, A.C. and Sikdar, B. (2013) Estimation of genetic diversity in six Lentil (Lens culinaris Medik.) varieties using morphological and biochemical markers. International Journal of 
Scientific \& Engineering Research, 4(9), September819 ISSN 2229-5518 2003.

Mishra, M.K., Narayana, S., Bhat, A.M., Nayani, S., Kumar, S. and Kumar, A. (2011) Genetic molecular analysis of Coffea arabica (Rubiaceae) hybrids using SRAP markers. Rev. Biol. Trop. 59(2), 607-617.

Pedalino, M., D-Urzo, M.P., Donnc, G.D., Grillo, S. and Rao, R. (1992) The structure of Cowpea (Vigna unguiculata L. Walp) seed storage proteins. Seed Sci. Technol. 2, 223-231.

Sammour, R. (2014) Cultivars identification based on biochemical markers. Research \& Reviews in BioSciences RRBS, 8(9), 347-358.

Sharma, S.K., Knox, M.R. and Ellis, T.H.N. (1996) AFLP analysis of the diversity and phylogeny of Lens and its comparison with RAPD analysis. Theor. Appl. Genet. 93, 751-758.

Sonnante, G. and Pignone, D. (2001) Assessment of genetic variation in a collection of lentil using molecular tools. Euphytica, 120, 301-307.

Sørensen, T. (1948) A method of establishing groups of equal amplitude in plant sociology based on similarity of species and its application to analyses of the vegetation on Danish commons. Kongelige Danske Videnskabernes Selskab. 5(4), 1-34.

Sultana, T., Ghafoor, A. and Ashraf, M. (2006) Geographic patterns of diversity of cultivated lentil germplasm collected from Pakistan, as assessed by seed protein assays. Acta Biol. Cracov. Bot. 48,7784.

Tello-Ruiz, M.K., Stein, J., Wei, S., Youens-Clark, K., Jaiswal, P. and Ware, D. (2016) Gramene: A resource for comparative analysis of plants genomes and pathways. Methods Mol. Biol. 1374,141-163.
Thavarajah, D., Thavarajah, P., Sarker, A., Materne, M., Vandemark, G., Shrestha, R., Idrissi, O., Hacikamiloglu, O., Bucak, B. and Vandenberg, A.A. (2011) Global survey of effects of genotype and environment on selenium concentration in lentils (Lens culinaris L.): Implications for nutritional fortification strategies. Food Chem. 125, 72-76.

Toklu, F., Karaköy, T., Hakle, I., Bicer, T., Brandolini, A., Kilian, B. and Ozkan, H. (2009) Genetic variation among lentil (Lens culinaris Medik.) landraces from Southeast Turkey. Plant Breed. 128, 178-186.

USDA National Nutrient Database for Standard Reference (2013) Available online: http://www.ars. usda.gov/Services/docs.htm?docid=8964 (accessed on 20 December 2013).

Yeboah, M.A., Xuehao, C., Feng, C.R., Liang, G. and $\mathrm{Gu}$, M. (2007) A genetic linkage map of cucumber (Cucumis sativus L.) combining SRAP and ISSR markers. Afr. J. Biotechnol. 6(24), 2784-2791.

Yüzbaşioğlu, E., Açik, L. and Özcan, S. (2008) Seed protein diversity among lentil cultivars. Biology of Plant, 52(1), 126-128.

Zaccardelli, M., Lupo, F., Piergiovanni, A.R., Aghetti, G., Sonnante, G., Daminati, M.G., Sparvoli, F. and Lioi, L. (2012) Characterization of Italian lentil (Lens culinaris Medik.) germplasm by agronomic traits, biochemical and molecular markers. Genet. Resour. Crop Evol. 59, 727-738.

Zhou, Y., Wang, X. and Zhang, X. (2011) Development and application of a SRAP marker for the identification of sex in Buchloe dactyloides. Euphytica, 181, 261-266. 


\title{
الخصائص والعلاقات الوراثية بين اصناف العدس المصرى باستخدام الدلائل البيوكيميائية والجزيئية \\ هاله محفوظ و ولاء ابو الوفا ريان \\ وحدة الور اثة ـ قسم النباتـ كلية العلوم- جامعة عين شمس ـ القاهرة- مصر.
}

\begin{abstract}
يعتبر محصول العدس من أهم المحاصيل الغذائية للإنسان ولكن حتى الآن لم يعرف إلا القليل عن تركيبه

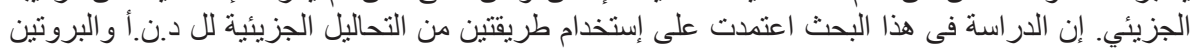

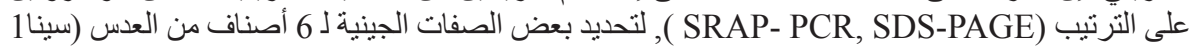

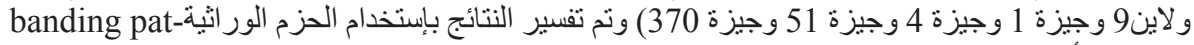
كالأتى: terns

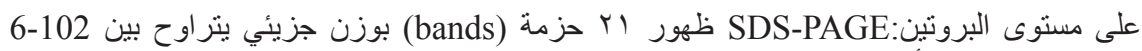

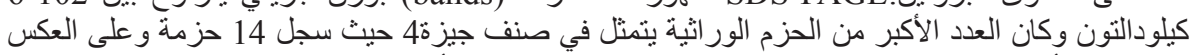

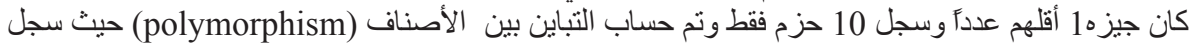
\% 80.95
\end{abstract}

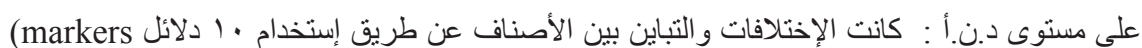

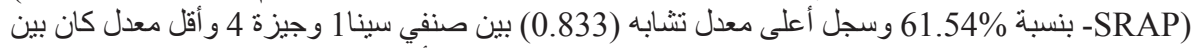

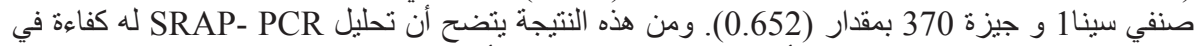
تعريف وتحديد الإختلافات بين هذه الأصناف للعدس و الذیى يمكن أن تستخدم في برنامج تربية النباتات. 